\title{
VARIJABILNOST KLONOVA U PROIZVODNJI ŽIRA I NJEZIN UČINAK NA EFEKTIVNE VELIČINE POPULACIJA I GENETSKU RAZNOLIKOST POTOMSTVA U KLONSKIM SJEMENSKIM PLANTAŽAMA HRASTA LUŽNJAKA (Quercus robur L.) U HRVATSKOJ
}

\section{VARIABILITY OF CLONES IN ACORN PRODUCTION AND ITS EFFECT ON EFFECTIVE POPULATION SIZES AND GENETIC DIVERSITY OF CROPS IN CLONAL SEED ORCHARDS OF PEDUNCULATE OAK (Quercus robur L.) IN CROATIA}

Ida KATIČIĆ BOGDAN'1, Davorin KAJBA', Saša BOGDAN¹

\section{SAŽETAK}

U ovom radu željeli smo ispitati različite parametre koji nam daju informaciju o učinkovitosti plantaža u proizvodnji genetski raznolikog potomstva. Koristili smo raspoložive inventurne podatke tvrtke "Hrvatske šume" d.o.o. o brojnom stanju i starosti rameta, te zabilježenim urodima u dvije klonske sjemenske plantaže hrasta lužnjaka; KSP "Plešćice" i KSP "Petkovac".

U slučaju KSP „Plešćice” korišteni su inventurni podaci, te podaci o urodu za 2003.,2006.,2007.,2008.,2009. i 2010. godinu. Nakon 2010. godine zbog organizacijskih se razloga prestalo pratiti urod po klonovima i prešlo se na evidentiranje ukupnog uroda na plantaži, pa je za period 2010.-2017. godine nemoguće procjeniti genetsku raznolikost uroda.

U slučaju KSP „Petkovac” korišteni su inventurni podaci, te podaci o urodu za 2003.,2004.,2005.,2006.,2008.,2009. i 2010. godinu. U slučaju KSP „Petkovac” također se nakon 2010. godine napustilo evidentiranje uroda po klonovima. Količine i varijabilnost uroda žira po godinama, kao i projekcije uroda za 2018. i 2019. godinu na temelju polinomijalnih regresijskih krivulja izračunali smo za sve godine evidentiranog uroda za cijelo razdoblje 2003. - 2017. godina. Rezultati su prikazani u tablici 1 i na slikama 1 i 2 . Sve druge analize bile su moguće samo za godine kada se sakupljanje žira u plantažama provodilo odvojeno po klonovima. Korelacijama po metodama Pearsona i Spearmana usporedili smo raspodjelu uroda žira između parova istraživanih godina po klonovima, odnosno poredak udjela klonova u urodima žira između istraživanih godina. Obje korelacije bile su većinom statististički značajne između parova godina, sa ponekim iznimkama (tablica 2).

Ravnoteža uroda klonova po godinama, opisana kumulativnim krivuljama proizvodnje žira po godinama, po postocima rodnih klonova, prikazana je na slikama 3 i 4 . Krivulje ravnoteže uroda klonova za obje plantaže prikazuju izrazito neravnomjernu raspodjelu uroda po klonova, što znači da je manjina klonova u istraživanim godinama

1Doc. dr. sc. Ida Katičić Bogdan, e-mail: ikaticic@sumfak.hr, prof. dr. sc. Davorin Kajba, e-mail: dkajba@sumfak.hr, prof. dr. sc. Saša Bogdan, e-mail: sbogdan@sumfak.hr. Sumarski fakultet, Sveučilište u Zagrebu, Zavod za šumarsku genetiku, dendrologiju i botaniku, Svetošimunska 25, 10000 Zagreb 
doprinosila većinskom količinom uroda. U uvjetima jednake plodnosti i sinkroniziranosti klonova doprinos u urodu bio bi razmjeran zastupljenosti klonova (clone size) tj. klonovi s većim brojem rameta značajnije bi doprinosili urodu. Iz tablice 3. može se primjetiti da je u slučaju KSP "Plešćice” ova korelacija bila slabija nego kod KSP "Petkovac". Dapače, u tri od šest promatranih godina ona uopće nije bila značajna. U slučaju KSP "Petkovac” korelacija je bila značajna u svim promatranim godinama

Procjena efektivnih veličina populacije i genetske raznolikosti potomstva po godinama prikazani su u tablici 4 . isključivo za žensku plodnost klonova. Prilikom izračuna doprinosa oba roditelja muška plodnost procijenjena je pomoću tri scenarija koja obuhvaćaju raznolik raspon potencijalnog muškog doprinosa u efektivnoj veličini populacije. Rezultati su prikazani u tablici 5. Usporedbom tri scenarija muškog doprinosa ukupnom efektivnom tj. statusnom broju $(\mathrm{Np})$ vidljivo je da su vrijednosti za prvi ,gdje je muški doprinos razmjeran udjelu rameta datog klona u ukupnom broju rameta, intermedijarne u odnosu na druga dva scenarija. Najniži efektivni brojevi roditelja $(N p)$, a time i najniži relativni efektivni brojevi $(N r)$, te najviše vrijednosti koeficijenta grupnog srodstva $(\Theta)$ dobivene su za drugi scenarij u kojem je muški doprinos jednak ženskome. Te su vrijednosti identične vrijednostima za samo žensku plodnost.

Najviši su efektivni brojevi i analogno druge vrijednosti dobivene za treći scenarij u kojem se pretpostavlja jednak muški doprinos svih klonova.

Za obje plantaže korelacija poretka ženskih efektivnih brojeva klonova za pojedine godine uroda, sa poretkom za količine uroda tih godina (po metodi Spearmana) je statistički značajna na razini $\mathrm{p}<0,05$.

Za primjenu mjera procjene genetske raznolikosti proizvedena u klonskim sjemenskim plantažama potrebna su sukcesivna višegodišnja praćenja cvjetanja/uroda, kao i saznanja o genetskoj dobiti dobivena testiranjem potomstva i uzgojne vrijednosti klonova u nedavno postavljenim testovima potomstva iz plantaža. Zbog svega toga je apsolutno preporučljivo da se daljnje sakupljanje uroda u ovim klonskim sjemenskim plantaža obavlja odvojeno po klonovima, jer se jedino na taj način, bez skupih molekularnih analiza, može doći do relevantnih informacija o doprinosu pojedinih klonova genetskoj raznolikosti potomstva.

KLJUČNE RIJEČI: Hrast lužnjak, klonske sjemenske plantaže, varijabilnost uroda po godinama, genetska raznolikost uroda, ravnoteža uroda klonova,

\section{UVOD}

\section{INTRODUCTION}

U Republici Hrvatskoj hrast lužnjak (Quercus robur L.) zauzima znatne površine, a ekološki i gospodarski predstavlja jednu od najvažnijih vrsta šumskog drveća.. Zbog pojave nepravilnosti periodiciteta uroda sjemena hrasta lužnjaka posljednjih desetljeća, pospješivanja otežane obnove sastojina, te povećanja genetske kvalitete sjemena, započeti su radovi na osnivanju klonskih sjemenskih plantaža (VIDAKović 1996) i prvih testova potomstva plus stabala iz slobodnog oprašivanja (BogdAN i dr. 2008, 2004, KAJBA i dr. 2011). U sadašnjoj sjemenskoj zoni Posavine, srednje Hrvatske i Pokuplja, te sjemenskoj zoni Podravine i Podunavlja selekcionirana su plus stabala s obzirom na deset ocjenjivanih svojstava, a nakon heterovegetativnog razmnožavanja osnovane su proizvodne klonske sjemenske plantaže (KSP) na području Uprave šuma Podružnice Vinkovci (KSP „Petkovac”), Bjelovar ( KSP „Plešćice”) i Našice (KSP „Kosovac”). Razmaci sadnje i način orezivanja koji se redovno primjenjuje u plantažama, sa ciljem postizanja optimalnog uzgojnog oblika i poboljšanja rodnosti rameta, opisan je u KaJBA i dr. 2007.

Jedna od važnijih uloga klonskih sjemenskih plantaža je i očuvanje genetske raznolikosti. Istraživanja su pokazala da genetska raznolikost prisutna u prirodnim populacijama može biti očuvana, čak i uvećana selekcijom određene skupine roditeljskih stabala u prvoj generaciji klonskih sjemenskih plantaža. Međutim, primjećeno je opadanje raznolikosti u potomstvu iz plantaža druge generacije, nakon smanjenja broja selekcioniranih klonova na osnovu rezultata iz testova potomstava ili klonskih testova (EL-KASSABY 2000). To ukazuje na posebnu važnost plantaža prve generacije za očuvanje genetske raznolikosti, čak i nakon završetka njihove proizvodne funkcije. Takve se plantaže nazivaju konzervacijskim plantažama i predstavljaju zasebnu kategoriju u očuvanju genetske raznolikosti (SKRøPPA 2005). Osnovni cilj dobrog genetičkog dizajna klonske sjemenske plantaže je postizanje maksimalne genetske dobiti, uz zadržavanje zadovoljavajuće genetske raznolikosti dobivenog potomstva (White i dr. 2007). Prvi korak u tom procesu je određivanje optimalnog broja klonova. U pravilu, u plantaže prve generacije koje se osnivaju s klonovima još netestiranih plus stabala, preporuča se uključiti relativno visok broj klonova (oko 60). S obzirom da će se na osnovu genetičkih testova izdvojiti klonovi slabije kvalitete, naknadno ih se može isključiti, kako bi se poboljšala genetska dobit. Bez obzira što je u tako uspostavljenim sjemenskim 
plantažama obuhvaćena značajna genetska raznolikost, one svakako sadrže ograničen broj genotipova u usporedbi sa sjemenskim sastojinama. S obzirom da je potomstvo proizvedeno u njima namjenjeno uporabi na širokom području, velika se pažnja mora posvetiti procjeni stvarne genetske raznolikosti tako proizvedenog potomstva (GöмÖRY i dr. 2008.)

Idealna sjemenska plantaža trebala bi funkcionirati kao Mendelijanska populacija sa nasumičnom oplodnjom u kojoj je vjerojatnost oplodnje između bilo koja dva genotipa u populaciji jednaka i neovisna o samim genotipovima (dakle, pretpostavlja se jednaka plodnost svih genotipova i nedostatak specifične sklonosti oplodnje između određenih genotipova). Dodatni preduvjet idealne plantaže je i jednaki vitalitet svog proizvedenog potomstva. Svi ti preduvjeti često nisu zadovoljeni u sjemenskim plantažama, poglavito klonskim.

Klonske sjemenske plantaže prve generacije uobičajeno se postavljaju bez prethodnih saznanja o plodnosti i uzgojnoj vrijednosti pojedinih klonova, te je u takvim uvjetima logično težiti tome da svi klonovi selekcioniranih plus stabala budu predstavljeni sa podjednakim brojem rameta. Međutim, iz različitih razloga taj je uvjet često narušen. Kao što navode KANG i dr. 2001a, u opsežnom istraživanju varijabilnosti efektivnog broja klonova u klonskim sjemenskim plantažama nekoliko vrsta u različitim zemljama, neki od razloga su: dostupnost materijala tj. različit uspjeh cijepljenja, razlike u kvaliteti cijepljenja ovisno o osobama koje cijepe, razlike u otpornosti na biotske i abiotske čimbenike nakon sadnje, razlike u kompatibilnosti sa podlogom, pogreške u označavanju rameta klonova, administrativne i financijske zapreke u nadopunjavanju itd. Sukladno tome, kao i stvarnim razlikama u plodnosti klonova, fenološkoj inkompatibilnosti između određenih parova, te genetske inkompatibilnosti (uključujući i samo-inkompatibilnost) koja dovodi do slabijeg vitaliteta određenog potomstva, može se očekivati gubitak genetske raznolikosti u potomstvu iz plantaža.

Uzimajući u obzir različite parametre koji utječu na stvaran broj roditelja koji će sudjelovati u genetskoj raznolikosti plantažnog potomstva, jasno je da sam ukupni broj klonova koji su uključeni u plantažu (tzv. Census number) ne daje ni približno dostatnu informaciju o funkcionalnosti konkretne plantaže u proizvodnji genetski raznolikog sjemena. Veliki utjecaj na stvarni efektivni broj roditelja ima već i utjecaj neravnopravne zastupljenosti različitih klonova u plantaži, ne uzimajući u obzir utjecaj plodnosti, fenologije i sličnih čimbenika po kojima se klonovi, a i same ramete, međusobno razlikuju.

Najveći doprinos razumijevanju procesa oplodnje u plantažama dala je primjena molekularno-genetičkih metoda, ponajviše jezgrinih mikrosatelitskih biljega u roditeljskoj analizi uzoraka potomstva iz plantaža. Pomoću takvih metoda može se dobiti jasan uvid u genetsku konstituciju potomstva iz plantaže, odstupanja od panmiksije, stupanj kontaminacije stranim peludom, udio pojedinih roditelja u potomstvu tj. efektivnu veličinu plantažne populacije itd. Međutim, takve su metode obično preskupe, da bi se rutinski provodile za dobivanje informacija o genetskoj raznolikosti potomstva za potrebe redovnog gospodarenja plantažama. Zbog toga se za procjenu genetske raznolikosti potomstva najčešće koriste različiti procjenitelji efektivne veličine populacije, čija preciznost ovisi o podacima s kojima se raspolaže.

LiNDGREN i dr. 1996 uvode tzv. Statusni (efektivni) broj, (Status (effective) number), koji je povezan sa konceptom Grupnog srodstva (Group coancestry $(\Theta)$ ), tj. vjerojatnošću da su dva gena nasumično uzorkovana iz nekog genetskog izvora jednakog podrijetla. Statusni broj je definiran kao polovica recipročne vrijednosti Grupnog srodstva $\left(\mathrm{N}_{\mathrm{s}}=\right.$ $0,5 / \Theta)$. On se može definirati kao "broj međusobno nesrodnih i jednako fertilnih genotipova u hipotetskoj idealnoj plantaži koji bi, nakon slobodnog oprašivanja među potomstvom tih genotipova, rezultirao jednakom količinom inbreedinga, kakvom će rezultirati slobodno oprašivanje među postojećim, stvarnim potomstvom genotipova iz određene plantaže."

GöMÖRY i dr. 2008 na primjeru dvije starije i jedne mlađe sjemenske plantaže običnog bora (Pinus sylvestris L.) prikazuju utjecaj različitih, lakše ili teže mjerljivih čimbenika na procjenu Statusnog broja, te ga uspoređuju sa jednostavnijim procjeniteljima efektivne veličine populacije. Naime, autori ispituju da li je Efektivan broj klonova $\left(\mathrm{N}_{\mathrm{c}}\right)$ (dakle, broj koji ovisi isključivo o broju rameta pojedinih klonova, podrazumjevajući njihovu jednaku plodnost, te slobodno oprašivanje) dobar pokazatelj stvarnog stanja očekivane genetske raznolikosti potomstva iz plantaža ili utjecaj čimbenika dodanih u izračun kompleksnijeg procjenitelja, Statusnog broja $\left(\mathrm{N}_{\mathrm{s}}\right)$, dovodi do značajnih odstupanja od tog jednostavnog procjenitelja. Ispitivani čimbenici su: opažanja ženske i muške plodnosti, fenološka opažanja, točan raspored i položaj rameta u plantaži tj. njegov utjecaj na vjerojatnost oprašivanja s obzirom na udaljenost među klonovima. $\mathrm{U}$ tom i prethodnom radu iste grupe autora (GöMöRY i dr. 2000) navedene su formule i detaljno opisani izračuni Statusnog broja i utjecaj navedenih čimbenika. Autori su došli do zaključka da utjecaj pojedinih čimbenika opada sa starošću plantaža. Naime, kod dvije starije plantaže, koje su već postigle puno plodonošenje, Efektivan broj klonova $\left(\mathrm{N}_{c}\right)$ pokazao se prilično dobrim procjeniteljem genetske raznolikosti plantažnih potomstava, (što znači da se dobiveni Statusni brojevi $\left(\mathrm{N}_{\mathrm{s}}\right)$ nisu uvelike razlikovali od njega). To ne znači da između klonova nisu postojale razlike u ženskoj, a poglavito muškoj plodnosti, ali one nisu značajno utjecale na smanjenje Statusnog broja. Dodavanje fenoloških razlika, te razlika u vjerojatnosti oprašivanja, s obzirom na udaljenost, nisu imale osobit utjecaj na smanjenje Statusnog broja. 
Dapače, u slučaju jedne od starijih plantaža fenološke razlike čak su dovele do učinka uravnoteživanja, jer je fenološka nesinkroniziranost nekih obilno cvjetajućih klonova sa ostatkom plantaže, povećala Statusni broj, smanjujući potencijalni udio tih roditeljskih genotipova u potomstvu.

Međutim, kod najmlađe plantaže situacija je drugačija. Efektivna veličina plantažne populacije primjetno se smanjuje uključenjem svakog novog čimbenika, pri čemu je Statusni broj u svakom od modela značajno manji od Efektivnog broja klonova. Takav rezultat je i očekivan kod mlađih plantaža gdje možemo očekivati veće razlike i nepravilnosti u cvatnji i plodonošenju, uzevši u obzir učinak razlike u dobi rameta, koji se postepeno gubi sa starošću plantaže. U dugogodišnjem istraživanju sjemenske plantaže običnog bora (Pinus sylvestris L.) u Danskoj, KJÆR i WellendorF (1998) također primjećuju postepenu promjenu Relativnog statusnog broja sa $29 \%$ na $81 \%$ u periodu od 20 godina.

\section{MATERIJAL MATERIAL}

U sklopu redovnog gospodarenja proizvodnim klonskim sjemenskim plantažama hrasta lužnjaka „Plešćice” i „Petkovac" provode se godišnje inventure brojnog stanja, sadnje novih, te odumiranja starih rameta.

U godinama kada su izvršene berbe žira zabilježen je urod žira ukupno po klonovima (ukupan urod svih rameta pojedinog klona) ili ukupan urod u cijeloj plantaži.

U slučaju KSP „Plešćice” korišteni su inventurni podaci, te podaci o urodu za 2003.,2006.,2007.,2008.,2009. i 2010. godinu. 2004. i 2005. godine, po navodu nadležnih djelatnika tvrtke „Hrvatske šume” d.o.o., urod je bio zanemariv, pa stoga nije evidentiran. Nakon 2010. godine zbog organizacijskih se razloga prestalo pratiti urod po klonovima i prešlo se na evidentiranje ukupnog uroda na plantaži, pa je za period 2010.-2017. godine nemoguće procjeniti genetsku raznolikost uroda.

U slučaju KSP „Petkovac” korišteni su inventurni podaci, te podaci o urodu za 2003.,2004.2005.,2006.,2008.,2009. i 2010. godinu. Za 2007. godinu postojao je samo podatak o ukupnoj masi uroda, koji je te godine bio vrlo nizak. U slučaju KSP „Petkovac” također se nakon 2010. godine napustilo evidentiranje uroda po klonovima i do 2017.godine nisu zabilježeni značajni urodi u plantaži.

\section{METODE} METHODS

\section{Količine i varijabilnost uroda žira po godinama - Amounts and variability of acorn crops in different years}

Količine uroda izmjerene su u kg žira, osim 2003, godine za KSP „Petkovac”, kad je zabilježen broj sakupljenih žireva.
Uziman je i uzorak žira po klonovima, te je na osnovu mase i broja žireva u uzorku izračunata prosječna masa žira po pojedinom klonu, s obzirom da je masa i veličina žira povezana s majčinskim stablom tj. genotipom (Ivanković i dr. 2011). Na osnovu tog podatka, te mase uroda po klonu za pojedinačne godine uroda, izračunat je urod u broju žireva po klonu, s obzirom da upravo taj podatak predstavlja broj potencijalnih potomaka iz uroda pojedinačnog klona. Statističke analize u nastavku provedene su po metodama opisanim u KANG i dr. (2010) i ERTEKIN (2010), u programu SAS Release 8.02 (SAS Institute, 2004). Za svaku godinu su izračunati brojevi žireva po klonu zbrojeni u ukupan broj žireva po plantaži. Potom je taj broj podijeljen sa ukupnim brojem klonova u plantaži i prikazan kao prosječan broj žireva po klonu. Za prikaz proizvodnje žireva kroz vrijeme, kao i projekcije budućih uroda, izrađene su polinomijalne regresijske krivulje, na osnovu prosječnih brojeva žireva po klonu, po godinama. Izračunat je koeficijent varijabilnosti $(\mathrm{CV})$ po godinama, po formuli:

$$
C V=\frac{s d}{M}
$$

gdje je: $s d$ standardna devijacija, a $M$ prosječni broj žireva po klonu.

Za urode u KSP „Plešćice” i „KSP „Petkovac”, u periodu 2011.-2017, kada se bilježio samo ukupni urod, broj žireva po klonu procijenjen je iz ukupne težine uroda sa prosječnom težinom žira svih klonova iz date plantaže, kako bi se na grafikonu prikazao trend plodonošenja u plantažama.

\section{Korelacija godina uroda - Correlation of crops of different years}

Korelacijske analize između uroda po godinama, po metodama Spermana i Pearsona (Pearson's product-moment i Spearman's rank correlations) izrađene su pomoću proc corr funkcije u sklopu programa SAS Release 8.02 (SAS Institute, 2004). Pearsonovom metodom uspoređuje se raspodjela uroda žira po klonovima između parova istraživanih godina, a Spearmanovom metodom uspoređuje se poredak udjela klonova u urodima žira između istraživanih godina.

\section{Ravnoteža uroda klonova - Clone fructification balance}

Ravnoteža uroda klonova je prikazana pomoću kumulativnih krivulja proizvodnje žira, koristeći metodu autora GRIFFIN (1982). Proizvodnja žira po klonu je rangirana uzlazno po količini i kumulativni postotci po klonovima su procijenjeni i stavljeni u odnos sa brojem klonova. Urod po klonovima u pojedinim godinama uspoređen je korelacijskom analizom po Pearsonu sa ukupnim brojem reproduktivno sposobnih rameta klonova. Na osnovu zapažanja zaposlenika na plantaži, kao reproduktivno sposobne, tj. redovito cvatuće, ocijenjene su ramete koje minimalno tri 
godine rastu u plantaži. Njihov broj po klonovima uzet je iz redovitih godišnjih inventura u plantažama. Korelacijska analiza izrađene su pomoću proc corr funkcije u sklopu programa SAS Release 8.02 (SAS Institute, 2004)

\section{Procjena efektivnih veličina populacije i genetske raznolikosti potomstva po godinama - Estimations of effective populations sizes and genetic diversity of crops in different years}

Plodnost klonova definirana je kao potencijalni reproduktivni kapacitet klona i uvjetovana je genetskim i okolišnim čimbenicima. Ženska plodnost u ovom slučaju procijenjena je na osnovu broja proizvedenih žireva po klonu, a muška plodnost pomoću tri potencijalna scenarija, kao u KANG i dr. (2010). Za procjenu efektivnih veličina populacija korišteni su izračuni efektivnih brojeva roditelja.

Ženski efektivni broj roditelja izračunat je na osnovu varijacija u plodnosti klonova (udjela pojedinačnih klonova u broju ukupno proizvedenih žireva), po formuli:

$$
N_{f}=\left(\sum_{i=1}^{N} f_{i}^{2}\right)^{-1}
$$

gdje je,

$N$ - ukupni broj klonova (Census number of clones)

$f_{i}$ - udio $i$-tog klona u ukupnoj količini proizvedenog žira

Muška plodnost procijenjena je pomoću tri scenarija koja obuhvaćaju raznolik raspon potencijalnog muškog doprinosa u efektivnoj veličini populacije. Te su mogućnosti uvrštene u izračun ukupnog efektivnog broja roditelja $N_{p}$, koji se također može nazvati i terminom „Statusni broj”.

Scenarij 1: Pretpostavka: Udio klona u ukupnoj muškoj plodnosti proporcionalan je udjelu broja rameta klona $\mathrm{u}$ ukupnom broju rameta u plantaži (tzv. veličini klona).

Pri izračunu veličine klona uzete su u obzir samo ramete dovoljno stare za cvatnju. Broj rameta pojedinog klona po godinama izračunat je na osnovu redovnih godišnjih inventura, uz oduzimanje procijenjenog broja rameta koje u datoj godini nisu bile zrele za cvatnju. Za godine 2003., 2004., 2005. i 2006. u KSP „Petkovac” podaci inventura nisu bili dostupni, ali je zabilježen točan broj rameta koje su rodile sa bilo kojom količinom žira. Taj je broj rameta korišten za izračun udjela potencijalnih muških roditelja, neovisno o konkretnom udjelu samog uroda tih rameta. Dakle, tako izračunat efektivni muški broj nije jednak ženskom, ali uzima u obzir samo ramete i klonove koji su rodili. Efektivni broj roditelja $N_{p}$ izračunat je po formuli:

$$
N_{p}=\left(\sum_{i=1}^{N} p_{i}^{2}\right)^{-1}=1 / \sum_{i=1}^{N}\left(\frac{f_{i}+r_{i}}{2}\right)^{2}
$$

gdje je, $p_{i}$ - ukupni roditeljski doprinos klona, izračunat kao sredina udjela klona u broju žira $f_{i}$ (ženski udio) i udjela klona u broju potencijalno cvjetajućih rameta $r_{i}$ (muški udio).

Scenarij 2: Pretpostavka - Udio klona u ukupnoj muškoj plodnosti proporcionalan je udjelu klona u urodu (ženskoj plodnosti) tj. postoji potpuna spolna simetrija. Efektivni broj roditelja $N_{p}$ izračunat je po formuli:

$$
N_{p}=\left(\sum_{i=1}^{N} p_{i}^{2}\right)^{-1}=1 / \sum_{i=1}^{N}\left(\frac{f_{i}+f_{i}}{2}\right)^{2}=N_{f}
$$

Scenarij 3: Pretpostavka - Udio klona u ukupnoj muškoj plodnosti jednak je za sve klonove i stoga iznosi $1 / N$, gdje je $N$ ukupni broj klonova u plantaži. Efektivni broj roditelja $N_{p}$ izračunat je po formuli:

$$
N_{p}=\left(\sum_{i=1}^{N} p_{i}^{2}\right)^{-1}=1 / \sum_{i=1}^{N}\left(\frac{f_{i}+1 / N}{2}\right)^{2}
$$

Pod pretpostavkom da klonovi nisu međusobno srodni, grupno srodstvo $\Theta$ (group co-ancestry) izračunato je po formuli:

$$
\Theta=0,5 \sum p_{i}^{2} \quad \text { tj. } \quad \Theta=\frac{1}{2 N_{p}}
$$

a očekivana genetska raznolikost uroda sjemena kao:

$$
G D=1-\Theta
$$

Relativni efektivni populacijski brojevi $N_{r}$ izračunati su kao:

$$
N_{r}=\frac{N_{p}}{N}
$$

Poredak ženskih efektivnih brojeva uspoređen je sa poretkom ukupnih količina uroda korelacijom po Spearmanu pomoću proc corr funkcije u sklopu programa SAS Release 8.02 (SAS Institute, 2004)

\section{REZULTATI}

\section{RESULTS}

\section{Količine i varijabilnost uroda žira po godinama - Amounts and variability of acorn crops in different years}

$\mathrm{U}$ tablici 1. prikazana je evidencija uroda po godinama u KSP "Plešćice" i KSP "Petkovac". Urod je u obje plantaže oscilirao po godinama, sa trendom povećanja ukupnih količina uroda, uz prisustvo lošijih godina kada je urod znatno opadao. U tablicu su uključene samo godine kada je u plantažama žir sakupljan po klonovima, tako da nisu prikazani urodi od 2011. - 2017. godine u KSP „Plešćice“ kada je evidentiran samo ukupan urod u plantaži. Najveći urod sakupljen po klonovima u obje plantaže zabilježen je 2010. go- 
dine sa prosječnim urodima po klonu 8752,3 \pm 12339,3 žireva za KSP "Plešćice”, te 4336,7 \pm 6227,5 žireva za KSP "Petkovac". 2010. godine je ujedno u KSP "Plešćice" rodilo i najviše klonova (53/53), dok je u KSP "Petkovac" najviše klonova rodilo 2008. godine (55/56). Svaki od klonova u obje plantaže rodio je barem jednom $\mathrm{u}$ istraživanom razdoblju. Pritom je urod bio prilično neujednačen po klonovima, što se vidi i iz visokih vrijednosti koeficijenata varijabilnosti $(C V)$. Koeficijenti varijabilnosti su obično manji kod obilnijih uroda, što znači da je ujednačenost doprinosa klonova veća. Kod obje plantaže može se primjetiti trend većeg $C V$ kod manjih uroda, premda koeficijenti nisu strogo rangirani kao i količine uroda. Najniža vrijednost CV za KSP "Plešćice” bio je u 2010. godini, kada je plantaža i najbolje urodila. Kod KSP "Petkovac" najniži $C V$ bio je u 2006. godini.

Kod KSP “Plešćice” nisu zabilježeni urodi za 2004. i 2005. godinu, ali iz osobne komunikacije sa nadležnim osobama iz tvrtke "Hrvatske šume" d.o.o. doznaje se da je tih godina urod bio zanemariv. Sličan je slučaj za 2007. godinu u KSP "Petkovac" gdje ne postoji evidencija uroda po klonovima, ali se ukupan urod procjenjuje na cca $15 \mathrm{~kg}$ (kao i npr. u 2004. godini).

Na slikama 1. i 2. prikazane su prosječne proizvodnje žira po klonu po godinama za KSP "Plešćice" odnosno "Petkovac" za razdoblje 2006.-2017. odnosno 2003.-2017. godine. Najveći ukupni urod od 8190 kg, odnosno cca 33733 žira

Tablica 1. Evidencija uroda u KSP „Plešćice“ i KSP „Petkovac“ po godinama za koje postoje podaci o urodima po klonovima. Nrk - broj svih klonova koji su rodili bilo kojom količinom uroda, Ukupno žireva - ukupan urod na plantaži, iskazan u broju žireva, Prosjek - Ukupno žireva podijeljeno s ukupnim brojem klonova u plantaži (53-Plešćice, 56-Petkovac). SD - standardna devijacija uroda žira. CV - koeficijent varijabilnosti uroda žira Table 1. Crop records in different years when acorns were collected per clone. Nfc - Number of clones that fructified that year, Acorns total - averall number of acorns in the entire crop of that year, Average - Acorns total divided by the overall number of clones in the orchard (53-Plešćice, 56-Petkovac), $S D$ - standard deviation of the crops, CV - coefficient of variability of the crops

\begin{tabular}{|c|c|c|c|c|c|c|c|}
\hline \multicolumn{8}{|c|}{ KSP „Plešćice“ / CSO „Plešćice } \\
\hline Godina / Year & 2003 & 2006 & 2007 & & 2008 & 2009 & 2010 \\
\hline Nrk/ Nfc & 31 & 38 & 42 & & 33 & 52 & 53 \\
\hline Ukupno žireva/ Acorns total & 3165 & 18991 & 46062 & & 4623 & 152506 & 463874 \\
\hline $\begin{array}{c}\text { Prosjek (žir/klon)/ Average } \\
\text { (acorns/clone) }\end{array}$ & 59,7 & 358,3 & 869,1 & & 87,2 & 2877,5 & 8752,3 \\
\hline SD & 151,5 & 1017,2 & 1472,7 & & 182,7 & 5840,3 & 12339,3 \\
\hline CV & 2,538 & 2,839 & 1,694 & & 2,095 & 2,030 & 1,410 \\
\hline \multicolumn{8}{|c|}{ KSP „Petkovac" / CSO „Petkovac" } \\
\hline Godina / Year & 2003 & 2004 & 2005 & 2006 & 2008 & 2009 & 2010 \\
\hline Nrk/ Nfc & 41 & 44 & 40 & 52 & 55 & 53 & 53 \\
\hline Ukupno žireva/ Acorns total & 5524 & 4580 & 9087 & 26359 & 184547 & 17228 & 242857 \\
\hline $\begin{array}{c}\text { Prosjek (žir/klon)/ Average } \\
\text { (acorns/clone) }\end{array}$ & 98,6 & 81,8 & 162,3 & 470,7 & 3295,5 & 307,6 & 4336,7 \\
\hline SD & 313,8 & 218,6 & 432,1 & 478,7 & 4341,4 & 413,5 & 6227,5 \\
\hline CV & 3,181 & 2,673 & 2,663 & 1,017 & 1,317 & 1,344 & 1,436 \\
\hline
\end{tabular}

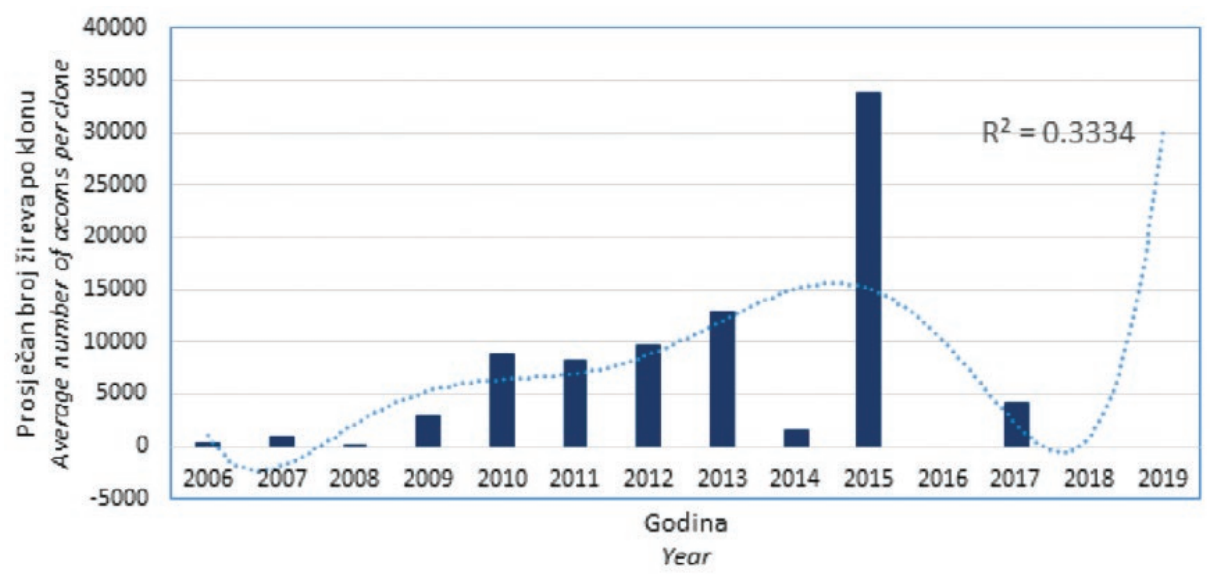

Slika 1. Grafički prikaz prosječne proizvodnje žira po klonu za KSP "Plešćice”, razdoblje 2006.-2017. godina. Dinamika uroda je aproksimirana polinomskom regresijskom krivuljom, s trendom za 2018. i 2019. godinu

Figure 1. Average production of acorns per clone in CSO "Plešćice" in the period of 2006. - 2017. Crop dynamics is approximated with a polynomial regression curve, including the trend for years 2018 and 2019 


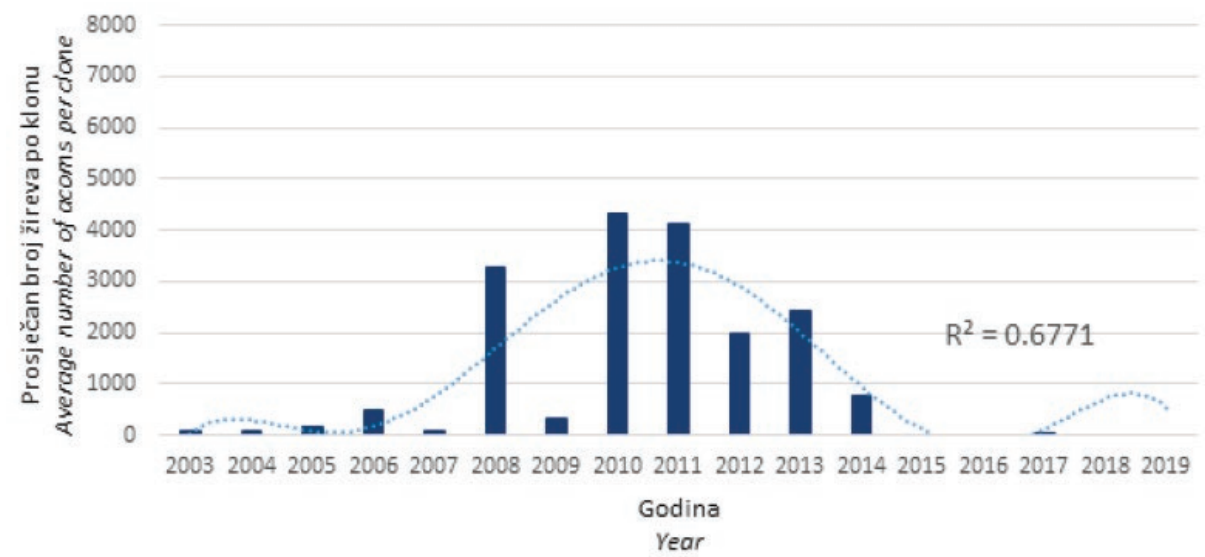

Slika 2. Grafički prikaz prosječne proizvodnje žira po klonu za KSP “Petkovac”, razdoblje 2003.-2017. godina. Dinamika uroda je aproksimirana polinomskom regresijskom krivuljom, s trendom za 2018. i 2019. godinu

Figure 2.. Average production of acorns per clone in CSO "Petkovac" in the period of 2003. - 2017. Crop dynamics is approximated with a polynomial regression curve, including the trend for years 2018 and 2019

po klonu zabiliežen je u KSP „Plešćice“ 2015. godine. U slučaju KSP „Petkovac“ najveći dosad evidentirani urod ostaje onaj iz 2010. godine. 2015. i 2016. godine urodi su bili slabi i nisu bili evidentirani.

Dinamiku uroda kroz godine najbolje opisuje polinomska regresijska krivulja ( $\mathrm{R}^{2}$ vrijednosti prikazane na grafikonima), pri čemu treba napomenuti da su obje plantaže još uvijek u uspostavljanju i vjerojatno je još uvijek prerano da bi pravi trend periodiciteta uroda bio vidljiv. Kod plantaže „Plešćice" bi se na osnovu modela polinomske regresije mo- glo očekivati relativno loš urod u 2018. godini, a porast uroda u 2019. godini, a kod KSP „Petkovac“ slabiji urodi u obje projicirane godine, ali bolji od zadnjeg uroda. Međutim, treba napomenuti da takva predviđanja nisu pouzdana, jer na količine uroda utječu brojni čimbenici.

\section{Korelacija godina uroda - Correlation of crops of different years}

U tablici 2. prikazani su Pearsonovi i Spearmanovi koeficijenti korelacije između godina uroda za koje postoje podaci

Tablica 2. Pearsonovi (zeleno) i Spearmanovi (crno) koeficijenti korelacije između godina uroda za KSP "Plešćice" i KSP "Petkovac". Crticama su označene godine za koje ne postoje dostatni podaci. ${ }^{* * *}$ označava značajno pri $P<0.001$; ${ }^{* *}$ značajno pri $P<0.01 ;{ }^{*}$ značajno pri $P<0.05$; bez oznake - nije značajno.

Table 2. Pearson (green) and Spearman (black) coefficients of correlation among crop years in CSO "Plešćice" and CSO "Petkovac". Hyphens mark the years without sufficient dana. ${ }^{* * *}$ significance of $P<0.001$; ${ }^{* *}$ significance of $P<0.01$; " significance of $P<0.05$; no mark - not significant.

\begin{tabular}{|c|c|c|c|c|c|c|c|c|}
\hline \multicolumn{9}{|c|}{ KSP „Plešćice” } \\
\hline & 2003 & 2004 & 2005 & 2006 & 2007 & 2008 & 2009 & 2010 \\
\hline 2003 & & - & - & $0.798^{* * *}$ & $0.655^{* * *}$ & 0,091 & 0,153 & $0.352^{* *}$ \\
\hline 2004 & - & & - & - & - & - & - & - \\
\hline 2005 & - & - & & - & - & - & - & - \\
\hline 2006 & $0.567^{* * *}$ & - & - & & $0.612^{* * *}$ & 0,104 & 0,182 & 0,270 \\
\hline 2007 & $0.317^{*}$ & - & - & $0.530^{* * *}$ & & $0.569^{* * *}$ & $0.573^{* * *}$ & $0.511^{* * *}$ \\
\hline 2008 & 0,263 & - & - & $0.383^{* *}$ & $0.674^{* * *}$ & & $0.709^{* * *}$ & $0.386^{* *}$ \\
\hline 2009 & 0,265 & - & - & $0.497^{* * *}$ & $0.659^{* * *}$ & $0.795^{* * *}$ & & $0.505^{* * *}$ \\
\hline 2010 & $0.398^{* *}$ & - & - & $0.567^{* * *}$ & $0.735^{* * *}$ & $0.722^{* * *}$ & $0.745^{* * *}$ & \\
\hline \multicolumn{9}{|c|}{ KSP „Petkovac” } \\
\hline & 2003 & 2004 & 2005 & 2006 & 2007 & 2008 & 2009 & 2010 \\
\hline 2003 & & $0.580^{* * *}$ & $0.907^{* * *}$ & 0,086 & - & $0.428^{* *}$ & 0,046 & $0.488^{* * *}$ \\
\hline 2004 & $0.749^{* * *}$ & & $0.867^{* * *}$ & 0,121 & - & $0.500^{* * *}$ & $0.379^{* *}$ & $0.482^{* *}$ \\
\hline 2005 & $0.727^{* * *}$ & $0.764^{* * *}$ & & 0,115 & - & $0.525^{* * *}$ & 0,224 & $0.539^{* * *}$ \\
\hline 2006 & $0.355^{* *}$ & 0,165 & 0,249 & & - & 0,095 & 0,114 & 0,019 \\
\hline 2007 & - & - & - & - & & - & - & - \\
\hline 2008 & $0.472^{* *}$ & $0.626^{* * *}$ & $0.635^{* * *}$ & 0,163 & - & & $0.529^{* * *}$ & $0.470^{* *}$ \\
\hline 2009 & $0.490^{* * *}$ & $0.503^{* * *}$ & $0.555^{* * *}$ & $0.290^{*}$ & - & $0.636^{* * *}$ & & $0.388^{* *}$ \\
\hline 2010 & $0.559^{* * *}$ & $0.643^{* * *}$ & $0.595^{* * *}$ & 0,085 & - & $0.724^{* * *}$ & $0.609^{* * *}$ & \\
\hline
\end{tabular}


uroda po klonovima, izračunati pomoću postotaka udjela pojedinih klonova u ukupnim urodima po godinama

Signifikantne vrijednosti Pearsonovih koeficijenata korelacije upućuju na to da je raspodjela količine uroda žira po klonovima gotovo svih istraživanih godina visoko korelirana sa raspodjelom uroda drugih godina, uz određene iznimke. Kod obje plantaže, a osobito kod KSP "Petkovac", 2006. godina ističe se kao neovisna, budući da je te godine raspodjela uroda po klonovima očigledno bila različitija od ostalih. Kod obje plantaže te je godine zabilježen dosta slab urod, premda ne i najslabiji. S obzirom da su neke godine slabijih uroda bile u puno boljoj korelaciji sa godinama najboljih uroda, na korelaciju nisu najviše utjecale razlike $\mathrm{u}$ količini ukupnog uroda.
Signifikantne vrijednosti Spearmanovih koeficijenata korelacije upućuju na to da je poredak klonova po udjelu u urodu gotovo svih godina također pod velikim utjecajem poredaka drugih godina. U ovom se slučaju kod KSP” Petkovac" ponovo ističe 2006. godina kao različitija od ostalih, dokje kod KSP "Plešćice” najveća razlika u odnosu na druge godine prisutna kod 2003. godine.

\section{Ravnoteža uroda klonova - Clone fructification balance}

Na slikama 3. i 4. prikazane su krivulje kumulativne proizvodnje žira po godinama, po postocima rodnih klonova. Ravna linija predstavlja idealnu situaciju u kojoj svi klonovi jednako doprinose urodu. Kut odstupanja krivulja od ravne

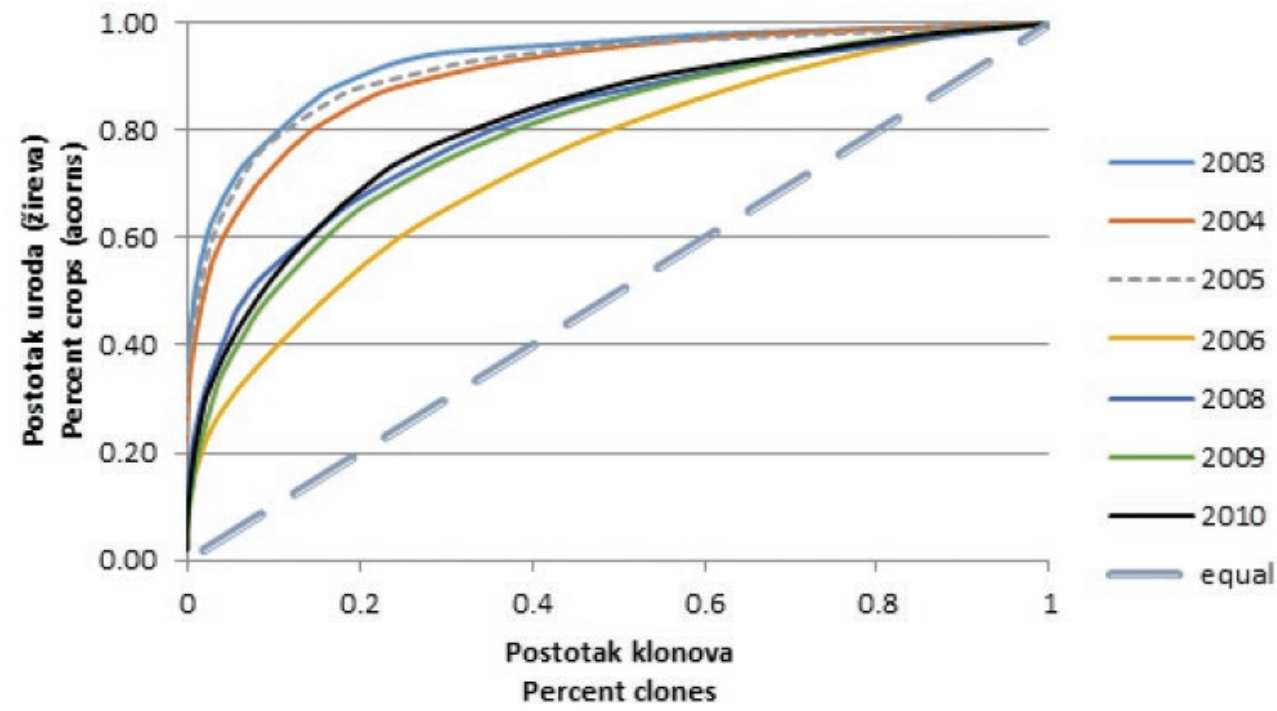

Slika 3. Krivulje kumulativne proizvodnje žira različitih godina u KSP "Plešćice"

Figure 3. Cumulative acorn production curves of different years in CSO "Plešćice"

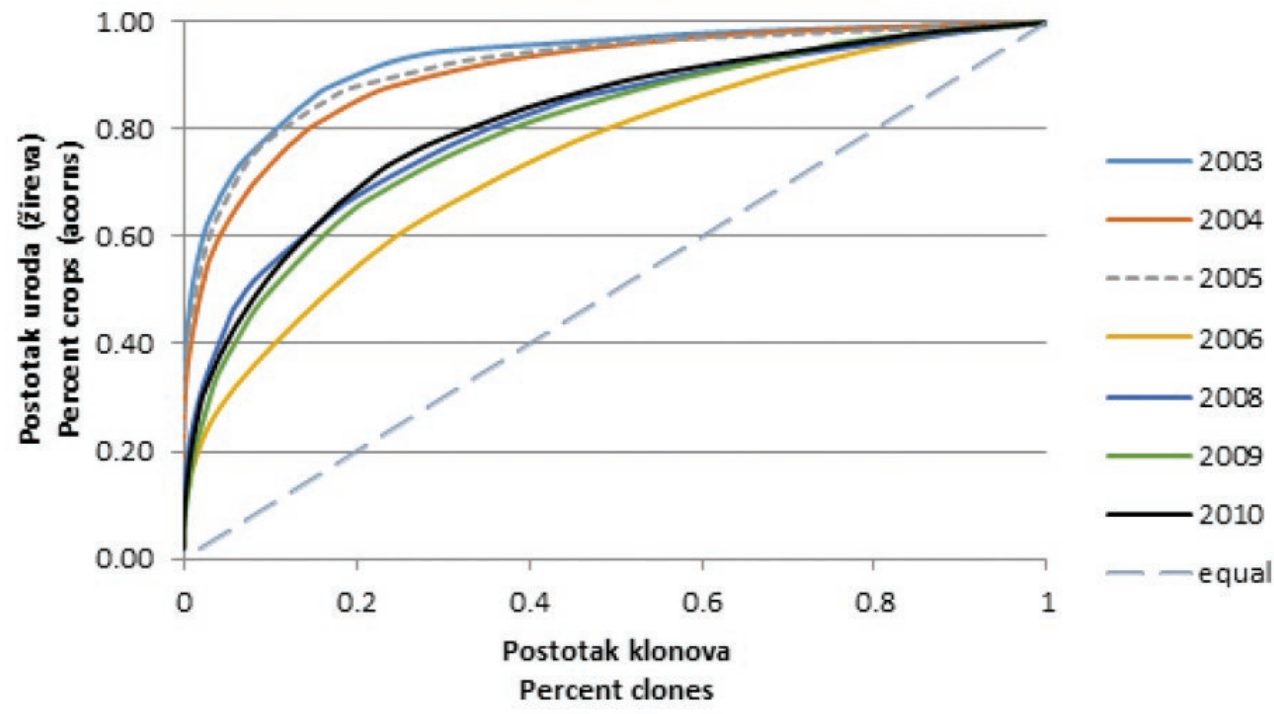

Slika 4. Krivulje kumulativne proizvodnje žira različitih godina u KSP "Petkovac"

Figure 4. Cumulative acorn production curves of different years in CSO "Petkovac" 
Tablica 3. Koeficijenti korelacije između udjela klonova u količini uroda i udjela klonova u broju rameta po godinama

Table 3. Coefficients of correlation between clone contribution in the amount of crops and clone contribution in the number of ramets in different years

$\begin{array}{lcccccccc}\text { God. / Year } & 2003 & 2004 & 2005 & 2006 & 2007 & 2008 & 2009 & 2010 \\ \text { KSP/CSO "Plešćice" } & 0,420^{*} & - & - & 0,218 & 0,345^{*} & 0,277 & 0,282 & 0,343^{*} \\ \text { KSP/CSO"Petkovac" } & 0,504^{* *} & 0,785^{* * *} & 0,498^{* * *} & 0,345^{*} & - & 0,460^{* *} & 0,485^{* * *} & 0,500^{* * *}\end{array}$

linije prikazuje koliko je u kojoj godini raspodjela uroda po klonovima odudarala od idealne situacije.

Krivulje ravnoteže uroda klonova za obje plantaže prikazuju izrazito neravnomjernu raspodjelu uroda po klonova, što znači da manjina klonova doprinosi većinskom količinom uroda.

U slučaju KSP "Plešćice" blizina krivulje idealnoj situaciji ovisila je o ukupnoj količini uroda; što je urod bio manji, to je situacija više odudarala od idealne. Pritom su krivulje donekle ravnomjerno razmaknute jedna od druge. Kod KSP "Petkovac" ne primjećuje se takva pravilnost. Tri najslabija, te tri najbolja uroda grupirala su se u odvojene, skupine krivulja, a specifična 2006. godina, bez obzira na relativno slab tj. osrednji urod, najviše se približila idealnoj situaciji jednakog doprinosa svih klonova.

U uvjetima jednake plodnosti i sinkroniziranosti klonova doprinos u urodu bio bi razmjeran zastupljenosti klonova (clone size) tj. klonovi s većim brojem rameta značajnije bi doprinosili urodu. U tablici 3. navedeni su koeficijenti korelacije između udjela klonova u urodu (broju žireva) i udjela klonova u broju procijenjeno reproduktivno sposobnih rameta.

Iz tablice 3. može se primjetiti da je u slučaju KSP "Plešćice" ova korelacija bila slabija nego kod KSP "Petkovac". Dapače, u tri od šest promatranih godina ona uopće nije bila značajna. U slučaju KSP "Petkovac" korelacija je bila značajna u svim promatranim godinama, s tim da je najslabija bila upravo u 2006. godini, kad su se udjeli u urodu najviše približili idealnoj situaciji.

\section{Procjena efektivnih veličina populacije i genetske} raznolikosti potomstva po godinama - Estimations of effective populations sizes and genetic diversity of crops in different years

U tablici 4. navedeni su slijedeći parametri: koeficijent grupnog srodstva $(\Theta)$, genetska raznolikost potomstva $(G D)$, ženski efektivni (ili statusni) broj roditelja ( $N f$ ), te relativni efektivni broj roditelja $(\mathrm{Nr})$, izračunati isključivo iz podataka o urodu za KSP "Plešćice i KSP "Petkovac". Ovi se parametri odnose samo na žensku plodnost klonova.

U tablici 5. parametri su izračunati za doprinos obaju roditelja, s tim da se muški doprinos promatra kroz tri teoretska scenarija, opisana u poglavlju Materijal i metode.

Korelacija poretka ženskih efektivnih brojeva klonova za pojedine godine uroda, sa poretkom za količine uroda tih godina (po metodi Spearmana) pokazuje da najveći efektivni brojevi nisu nužno vezani za visoke količine uroda, ali definitivno postoji takva tendencija, s obzirom na visoku korelaciju tih poredaka (KSP "Plešćice" $\mathrm{R}=0,77, \mathrm{KSP}$ "Petkovac" $\mathrm{R}=0,72)$. Za obje plantaže korelacija je statistički značajna na razini $\mathrm{p}<0,05$. (rezultati nisu tablično prikazani).

Kod KSP "Plešćice" najviši relativni ženski efektivni broj (Nrf) bio je u godini najvećeg uroda 2010. i iznosio je 0,34, dok se kod KSP "Petkovac" opet ističe 2006. godina, bez obzira na manju količinu uroda, sa Nrf od 0,52. U godini najvećeg uroda (2010.) u KSP "Petkovac" taj je broj iznosio 0,39.

Najviša genetska raznolikost potomstva (GD), pod pretpostavkom da klonovi nisu međusobno srodni, kod KSP “Ple-

Tablica 4. koeficijent grupnog srodstva $(\Theta)$, genetska raznolikost potomstva (GD), ženski efektivni (ili statusni) broj roditelja (Nf), te relativni efektivni broj roditelja (Nrf) za $\odot$ plodnost (proizvodnju žira)

Table 4. group coancestry $(\Theta)$, genetic diversity of crops $(\mathrm{GD})$, female effective (status) number of parents (Nf) and relative effective number of parents (Nrf) for female fecundity (acorn production).

\begin{tabular}{|c|c|c|c|c|c|c|c|c|c|}
\hline \multicolumn{10}{|c|}{ KSP "Plešćice" / CSO "Plešćice" } \\
\hline & 2003 & 2004 & 2005 & 2006 & 2007 & 2008 & 2009 & 2010 & ukupno \\
\hline$\Theta$ & 0,0690 & - & - & 0,0840 & 0,0360 & 0,0501 & 0,0476 & 0,0278 & 0,0262 \\
\hline $\mathrm{GD}$ & 0,9310 & - & - & 0,9160 & 0,9640 & 0,9499 & 0,9524 & 0,9722 & 0,9737 \\
\hline $\mathrm{Nf}$ & 7,24 & - & - & 5,95 & 13,88 & 9,99 & 10,51 & 17,97 & 19,04 \\
\hline Nrf & 0,14 & - & - & 0,11 & 0,26 & 0,19 & 0,20 & 0,34 & 0,36 \\
\hline \multicolumn{10}{|c|}{ KSP "Petkovac" / CSO "Petkovac" } \\
\hline & 2003 & 2004 & 2005 & 2006 & 2007 & 2008 & 2009 & 2010 & ukupno \\
\hline$\Theta$ & 0,0977 & 0,0716 & 0,0711 & 0,0180 & - & 0,0241 & 0,0248 & 0,0270 & 0,0203 \\
\hline $\mathrm{GD}$ & 0,9023 & 0,9284 & 0,9289 & 0,9820 & - & 0,9759 & 0,9752 & 0,9730 & 0,9797 \\
\hline $\mathrm{Nf}$ & 5,12 & 6,99 & 7,03 & 27,78 & - & 20,71 & 20,19 & 18,51 & 24,66 \\
\hline Nrf & 0,10 & 0,13 & 0,13 & 0,52 & - & 0,39 & 0,38 & 0,35 & 0,47 \\
\hline
\end{tabular}


Tablica 5. koeficijent grupnog srodstva $(\Theta)$, efektivni (ili statusni) broj roditelja (Np), te relativni efektivni broj roditelja (Nr) za ukupni roditeljski doprinos, izračunat pomoću tri scenarija za ổ plodnost

Table 5. group coancestry $(\Theta)$, effective (status) number of parents (Np) and relative effective number of parents (Nr) for overall parental contribution, based on three scenarios for male fecundity.

\begin{tabular}{|c|c|c|c|c|c|c|c|c|c|}
\hline \multicolumn{10}{|c|}{ KSP "Plešćice" / CSO "Plešćice" } \\
\hline & \multicolumn{3}{|c|}{ Scenarij 1 / Scenario 1} & \multicolumn{3}{|c|}{ Scenarij 2 / Scenario 2} & \multicolumn{3}{|c|}{ Scenarij 3 / Scenario 3} \\
\hline & $\Theta$ & $\mathrm{Np}$ & $\mathrm{Nr}$ & $\Theta$ & $\mathrm{Np}$ & $\mathrm{Nr}$ & $\Theta$ & $\mathrm{Np}$ & $\mathrm{Nr}$ \\
\hline 2003 & 0,0294 & 16,98 & 0,32 & 0,0690 & 7,24 & 0,14 & 0,0243 & 20,54 & 0,39 \\
\hline 2006 & 0,0294 & 17,03 & 0,32 & 0,0840 & 5,95 & 0,11 & 0,0281 & 17,80 & 0,34 \\
\hline 2007 & 0,0172 & 29,08 & 0,55 & 0,0360 & 13,88 & 0,26 & 0,0161 & 31,10 & 0,59 \\
\hline 2008 & 0,0207 & 24,20 & 0,46 & 0,0501 & 9,99 & 0,19 & 0,0196 & 25,52 & 0,48 \\
\hline 2009 & 0,0203 & 24,59 & 0,46 & 0,0476 & 10,51 & 0,20 & 0,0190 & 26,36 & 0,50 \\
\hline 2010 & 0,0153 & 32,77 & 0,62 & 0,0278 & 17,97 & 0,34 & 0,0140 & 35,63 & 0,67 \\
\hline \multicolumn{10}{|c|}{ KSP "Petkovac" / CSO "Petkovac" } \\
\hline & \multicolumn{3}{|c|}{ Scenarij 1 / Scenario 1} & \multicolumn{3}{|c|}{ Scenarij 2 / Scenario 2} & \multicolumn{3}{|c|}{ Scenarij 3 / Scenario 3} \\
\hline & $\Theta$ & $\mathrm{Np}$ & $\mathrm{Nr}$ & $\Theta$ & $\mathrm{Np}$ & $\mathrm{Nr}$ & $\Theta$ & $\mathrm{Np}$ & $\mathrm{Nr}$ \\
\hline 2003 & 0,0432 & 11,57 & 0,22 & 0,0977 & 5,12 & 0,10 & 0,0316 & 15,81 & 0,30 \\
\hline 2004 & 0,0393 & 12,72 & 0,24 & 0,0716 & 6,99 & 0,13 & 0,0251 & 19,92 & 0,38 \\
\hline 2005 & 0,0316 & 15,82 & 0,30 & 0,0711 & 7,03 & 0,13 & 0,0250 & 20,01 & 0,38 \\
\hline 2006 & 0,0128 & 39,13 & 0,74 & 0,0180 & 27,78 & 0,52 & 0,0117 & 42,70 & 0,81 \\
\hline 2008 & 0,0140 & 35,64 & 0,67 & 0,0241 & 20,71 & 0,39 & 0,0132 & 37,75 & 0,71 \\
\hline 2009 & 0,0144 & 34,62 & 0,65 & 0,0248 & 20,19 & 0,38 & 0,0134 & 37,31 & 0,70 \\
\hline 2010 & 0,0147 & 34,05 & 0,64 & 0,0270 & 18,51 & 0,35 & 0,0140 & 35,81 & 0,68 \\
\hline
\end{tabular}

šćice" procijenjena je za godinu najvećeg uroda 2010. i iznosila je $G D=0,9722$, dok je kod KSP "Petkovac" najviša bila u 2006. godini; $G D=0,9820$. S obzirom da je ona usko vezana uz koncept efektivnog tj. statusnog broja, smanjuje se sa njegovim smanjenjem.

Usporedbom tri scenarija muškog doprinosa ukupnom efektivnom tj. statusnom broju $(N p)$ vidljivo je da su vrijednosti za prvi ,gdje je muški doprinos razmjeran udjelu rameta datog klona u ukupnom broju rameta, intermedijarne u odnosu na druga dva scenarija. Najniži efektivni brojevi roditelja $(N p)$, a time i najniži relativni efektivni brojevi $(\mathrm{Nr})$, te najviše vrijednosti koeficijenta grupnog srodstva $(\Theta)$ dobivene su za drugi scenarij u kojem je muški doprinos jednak ženskome. Te su vrijednosti identične vrijednostima za samo žensku plodnost. Najviši su efektivni brojevi i analogno druge vrijednosti dobivene za treći scenarij u kojem se pretpostavlja jednak muški doprinos svih klonova.

\section{RASPRAVA DISCUSSION}

Oplemenjivanje šumskog drveća pomoću tri osnovna koraka; križanja, testiranja i selekcije, nastoji izdvojiti elitne jedinke za uspostavu proizvodnih populacija odnosno sjemenskih plantaža. Takve plantaže u proizvodnji reprodukcijskog materijala za podizanje budućih sastojina nastoje obuhvatiti genetsku dobit postignutu oplemenjivanjem, te zadržati zadovoljavajuću razinu genetske raznolikosti (EL KASSABY 2000). Od sjemenskih plantaža se očekuje da djeluju kao zatvorene, savršene populacije u Hardy-Weinbergo- voj ravnoteži, kako bi alelne i genotipske frekvencije potomstva dobro predstavljale odabrane roditeljske populacije. U te svrhe nastoji se postići maksimalna jednakost reproduktivnog uspjeha klonova, njihova fenološka sinkroniziranost, te minimalni inbriding i kontaminacija stranom peludi. Idealni uvjeti gotovo nikad nisu postignuti, međutim uspjeh sjemenskih plantaža u očuvanju genetske raznolikosti i ostvarenju genetske dobiti često su zadovoljavajući, usprkos odstupanjima od idealnog modela (XIANG i dr. 2003.)

Poznavanje varijabilnosti plodnosti klonova svakako je ključan čimbenik za gospodarenje sjemenskim plantažama; pogotovo za točan uvid u uspjeh sjemenske proizvodnje, te za predviđanje genetske raznolikosti uroda (KANG i dr. 2001a, 2001b). Postoje razne metode za praćenje ženske i muške plodnosti, koje se temelje na praćenju npr. cvatnje ili uroda, pri čemu je praćenje ženske plodnosti sigurnije i isplativije iz više razloga; 1) Sjeme je glavni izvor prihoda iz sjemenskih plantaža, 2) mnogo peludi dolazi iz vanjskih izvora (kontaminacija), dok se za sjeme pouzdano zna da potječe iz plantaže, 3) sjeme se može sabrati sa poznate majke i prebrojiti, te time dobiti pouzdan podatak o broju uspješnih gameta datog roditelja. Za razliku od navedenog, teže je procijeniti muški doprinos samo praćenjem količine proizvedenog peluda (Prescher i dr. 2007). Međutim, FundA i dr. (2009) navode brojne studije koje ukazuju na slabu korelaciju muške i ženske plodnosti unutar raznih plantaža, te ističu važnost spoznaja i o muškoj plodnosti za razvijanje točnijih matematičkih modela za optimizaciju genetske dobiti i genetske raznolikosti u potomstvu iz sjemenskih plantaža. 
Dvije klonske sjemenske plantaže u ovom istraživanju još su relativno mlade, jer se i dalje nadopunjuju rametama. Stoga ne ispunjavaju u potpunosti svoju funkciju, niti količinama uroda, niti proizvedenom genetskom raznolikošću. Kod mladih plantaža puno je vidljiviji i jači utjecaj pojedinačnih odstupanja od idealne populacije u kojoj potomstvo nastaje slobodnim oprašivanjem klonova, kao što su nejednakost u plodnosti, fenološka nesinkroniziranost i slično (GömöRY i dr. 2008). Nepovoljni utjecaji najčešće su vidljiviji i u godinama lošeg uroda, što je uglavnom potvrđeno i u ovom istraživanju (tablica 4 , slike 3., 4.). Ta se tendencija dobro vidi na podacima iz KSP „Plešćice“, a pokazuje neka odstupanja za KSP „Petkovac“, gdje se 2006. godina izdvaja po najboljim vrijednostima svih traženih parametara, bez obzira što količina uroda nije bila najveća te godine. Na njenu specifičnost dodatno upućuje činjenica da su genetska raznolikost potomstva i statusni brojevi povoljniji čak i od istih parametara za ukupno promatrano razdoblje (tablica 4). Uobičajen je slučaj, a to je potvrđeno i u KSP „Plešćice“, kao i u ostalim godinama uroda iz KSP „Petkovac“, da su procjene tih parametara za metapopulaciju potomstva u svim godinama više od pojedinačnih godina, zbog čega se ponekad preporuča korištenje šumskog reprodukcijskog materijala iz više uroda, radi povećanja genetske raznolikosti budućih sastojina (ERTEKIN, 2010).

$\mathrm{Za}$ točniju interpretaciju podataka o urodu neophodna su daljnja praćenja, podržana snimanjem meteoroloških uvjeta na samim plantažama, te sustavnim praćenjem djelovanja štetnika i elementarnih nepogoda. Od velike bi koristi bilo i provođenje DNK analize potomstva iz plantaža, radi jasne slike o obrascu oplodnje unutar plantaža, postotku kontaminacije, te mogućnosti procjene točnosti podataka o genetskoj raznolikosti potomstva, dobivenih jednostavnijim metodama praćenja cvjetanja i uroda. FunDA i dr. (2011), na primjeru plantaža četinjača, usporedbom rezultata DNK analize genetske raznolikosti potomstva pomoću jezgrinih mikrosatelita i procjene raznolikosti jednostavnijim i jeftinijim metodama praćenja cvjetanja i uroda, dolaze do zaključka da su potonje dovoljno precizne u procjeni prave raznolikosti. Pri tome ustanovljuju koje metode procjene efektivnog i statusnog broja, te genetske raznolikosti su najtočnije. Na sličan način bilo bi dobro usporediti i procjene dobivene ovim istraživanjem.

Što se tiče različitih scenarija muškog doprinosa u plantažama (tablica 5), jasno je da oni predstavljaju samo grubu teoretsku prepostavku stvarnog doprinosa, koja pritom i ne uzima u obzir doprinos kontaminacije stranom peludi. KANG i dr. (2010) primjenjuju iste scenarije za plantažu hrasta Quercus acutissima i na temelju osobnog promatranja zaključuju da je prvi scenarij, u kojem je muški doprinos razmjeran broju rameta, najrealniji. $\mathrm{Na}$ tom tragu su i okvirne informacije dobivene sa terena za KSP „Petkovac“. Naime, navodno se na većini reproduktivno sposobnih rameta mogu pronaći muški cvjetovi, ali ne postoje podaci o njihovoj obilnosti na konkretnim rametama/klonovima. S obzirom da se inače muški doprinos ne može potpuno jasno odrediti, jer se bez DNK analize ne može točno potvrditi koji je broj gameta rezultirao plodovima, već samo procijeniti na temelju obilnosti praćenog cvjetanja, pretpostavit će se da je i u slučaju ovih plantaža procjena ukupnog efektivnog broja najrealnija za prvi scenarij. Za točniju procjenu potrebno je provesti sistematsko praćenje muškog cvjetanja, te potvrditi njegovu učinkovitost provedbom DNK analize (KANG i dr. 2010).

Rezultati za žensku plodnost (tablica 4) ukazuju na loše stanje jednakosti reproduktivnog uspjeha u plantažama, ali postoji tendencija poboljšanja sa povećanjem količine uroda. S obzirom da se sjemenske plantaže još uvijek nadopunjavaju i da su klonovi neravnomjerno zastupljeni rametama zbog različite uspješnosti primitka i osjetljivosti pojedinih klonova, jednaki doprinos još ne može biti postignut. U ovoj dobi plantaža, efektivni broj klonova još je pod velikim utjecajem odstupanja uvjeta u plantaži od uvjeta idealne populacije. Sa starošću plantaža klonovi se sve više ujednačavaju i utjecaj pojedinačnih čimbenika, kao što je fenološka nesinkroniziranost, postaje manji. Npr. u ove dvije plantaže klonovi pokazuju fenološku nesinkroniziranost (Franjıć i dr. 2011, 2009), međutim teoretski izračuni ukazuju na to da glavni utjecaj na genetsku kompoziciju potomstva iz zrelijih plantaža ima obilnost, a ne vrijeme cvjetanja pojedinih klonova (GöMöRY i dr. 2008, Prescher i dr. 2007). Kod sjemenskih plantaža prve generacije, gdje roditelji nisu u međusobnom srodstvu, glavni uzrok genetske erozije potomstva upravo je razlika u plodnosti klonova, a ne samooplodnja (KANG i dr. 2010). Stoga poseban naglasak treba staviti upravo na postizanje što ravnopravnije zastupljenosti klonova primjenom različitih mjera, kao što su genetski utemeljene prorede ili selektivno sabiranje sjemena (FUNDA i dr. 2009). Autori također navode da je plodnost klonova u pravilu varijabilna tijekom godina i da modele sabiranja uroda i postizanja maksimalne genetske raznolikosti i dobiti u potomstvu treba primjenjivati na osnovu konkretnih uroda date godine. S većom starošću plantaža očekuje se obilnije i genetski uravnoteženije urode i tada je moguće primjeniti odgovarajuće modele selektivnog sabiranja sjemena (FundA i dr. 2009), kako bi se postigla maksimalna dobit i zadovoljavajuća genetska raznolikost šumskog reprodukcijskog materijala.

Dakako, za primjenu tih mjera potrebna su sukcesivna višegodišnja praćenja cvjetanja/uroda, kao i saznanja o genetskoj dobiti dobivena testiranjem potomstva i uzgojne vrijednosti klonova. Zbog svega toga je apsolutno 
preporučljivo da se daljnje sakupljanje uroda u ovim klonskim sjemenskim plantaža obavlja odvojeno po klonovima, jer se jedino na taj način može doći do relevantnih informacija o doprinosu pojedinih klonova genetskoj raznolikosti potomstva.

\section{LITERATURA}

\section{REFERENCES}

- BOGDAN, S., D. BEDENIKOVIĆ, M. IVANKOVIĆ, 2008: Rezultati genetičkog testa s familijama dobivenim slobodnim oprašivanjem plus stabala hrasta lužnjaka (Quercus robur L.) iz sjemenske regije Srednja Podravina, Radovi, 43 (2): 93-114, Jastrebarsko

- BOGDAN, S., D. KAJBA, I. KATIČIĆ, 2004: Genetic Variation in Growth Traits in a Quercus robur L. Open-Pollinated Progeny Test of the Slavonian Provenance. Silvae Genet, 53 (5-6): 198-201, Frankfurt

- EL-KASSABY, Y.A., 2000: Effect of forest tree domestication on gene pools. U: A.YOUNG, D. BOSHIER, T. BOYLE, (ur.) Forest Conservation Genetics: Principles and Practice. Commonwealth Scientific and Industrial Research Organisation (CSIRO). CSIRO Publishing-CABI Publishing, 13: 197-213, Canberra

- ERIKSSON, G., I. EKBERG, 2001: An Introduction to Forest Genetics. Chapter 6: 60-61 SLU, Uppsala.

- ERTEKIN M., 2010: Clone Fertility and Genetic Diversity in a Black Pine Seed Orchard. Silvae Genet 59 (4): 145-151, Frankfurt

- FRANJIĆ J., K. SEVER, S. BOGDAN, Ž. ŠKVORC, D. KRSTONOŠIĆ, I. ALEŠKOVIĆ, 2011: Phenological Asynchronization as a Restrictive Factor of Efficient Pollination in Clonal Seed Orchads of Pedunculate Oak (Quercus robur L.). CROJFE, 32 (1): 141-156, Zagreb

- FRANJIĆ J., S. BOGDAN, Ž. ŠKVORC, K. SEVER, D. KRSTONOŠIĆ.,2009: Phenological synchronisation of pedunculate oak clones from clonal seed orchards in Croatia. U: Matić S \& Anić I (ur.), Zbornik radova sa znanstvenog skupa: Šume hrasta lužnjaka u promjenjenim stanišnim i gospodarskim uvjetima HAZU- Centar za znanstveni rad Vinkovci: 153-168, Vinkovci - Zagreb

- FUNDA T., C. LIEWLAKSANEEYANAWIN, I. FUNDOVA, B.S.K. LAI, C. WALSH, i dr., 2011: Congruence between clonal reproductive investment and success as revealed by DNA-based pedigree reconstruction in seed orchards of lodgepole pine, Douglas-fir, and western larch, Can J Forest Res, 41: 380-389, Ottawa

- FUNDA T., M. LSTIBURAK, P. LACHOUT, J. KLAPSTE, Y.A. EI-KASSABY, 2009: Optimization of combined genetic gain and diversity for collection and deployment of seed orchard crops. Tree Genet Genom 5(4): 583-593, Heidelberg

- GÖMÖRY, D., R. BRUCHÁNIK, L. PAULE, 2000: Effective population number estimation of three Scots pine (Pinus sylvestris L.) seed orchards based on an integrated assessment of flowering, floral phenology, and seed orchard design. Forest Genetics 7(1): 65-75, Zvolen

- GÖMÖRY D., R. LONGAUER, L. PAULE, R. BRUCHÁNIK, 2008: Factors affecting effective population size estimation in a seed orchard: a case study of Pinus sylvestris, U: LINDGREN D (ur.) Seed Orchard Conference, Umeå, Sweden, 26-28 September 2007: 242-254, Umeå

- GRIFFIN A.R., 1982: Clonal variation in radiata pine seed orchards. I. Some flowering, cone and seed production traits. Aust For Res 12: 295-302, Canberra

- IVANKOVIĆ, M., M. POPOVIĆ, S. BOGDAN, 2011: Varijabilnost morfometrijskih svojstava žireva i visina sadnica hrasta lužnjaka (Quercus robur L.) iz sjemenskih sastojina u Hrvatskoj. Sumar List 135(13): 46-57, Zagreb

- KAJBA D., I. KATIČIĆ, S. BOGDAN, 2011: Estimation of Genetic Parameters in Open Pollinated Progeny Trials from Plus Trees of Pedunculate Oak (Quercus robur L.) Selected in Posavina and Podravina and Podunavlje Seed Zones CROJFE, 32 (1): 177-192, Zagreb

- KAJBA, D., N. PAVIČIĆ, S. BOGDAN, I. KATIČIĆ, 2007: Pomotehnički zahvati u klonskim sjemenskim plantažama listača. Sumar List, 131 (11-12): 523-528, Zagreb

- KANG, K. S., A. M. HARJU, D. LINDGREN, T. NIKKANEN, C. ALMKVIST, G. U. SUH, 2001a: Variation in effective number of clones in seed orchards. New For. 21: 17-33, Berlin

- KANG, K. S., D. LINDGREN, T. J. MULLIN, 2001b: Prediction of genetic gain and gene diversity in seed orchard crops under alternative management strategies. Theor Appl Genet 103: 1099-1107, Berlin

- KANG, K.S., C.S. KIM, Y.A. EL-KASSABY, 2010: Clonal variation in acorn production and its effect on effective population size in a Quercus acutissima seed orchard. Silvae Genet 59 (4): 170-175, Frankfurt

- KJÆR, E.D., H. WELLENDORF, 1998: Studies on the effect of unequal flowering on the effective population number in Danish seed orchard crops. Forest Tree Improvement 26(5): 1-9, Copenhagen

- LINDGREN, D., L.D. GEA, P.A. JEFFERSON, 1996: Loss of genetic diversity monitored by status number. Silvae Genet 45:5259, Frankfurt

- PRESCHER F., D. LINDGREN, C. ALMQVIST, J. KROON, T. A. LESTANDER, T. J. MULLIN, 2007: Female fertility variation in mature Pinus sylvestris clonal seed orchards. Scand J For Res 22(4): 280-289, Stockholm

- SAS Institute, 2004: SAS/STAT" 9.1 User's Guide. SAS Institute Inc., Cary, NC.

- SKRØPPA T., 2005: Ex situ conservation methods. U: Th. Geburek, J. Turok (ur.), Conservation and Management of Forest Genetic Resources in Europe. Arbora, 567-581, Zvolen

- VIDAKOVIĆ, M., 1996: Podizanje klonske sjemenske plantaže hrasta lužnjaka. U: KLEPAC, D. (ur.) Hrast lužnjak (Quercus robur L.) u Hrvatskoj. HAZU, Centar za znanstveni rad Vinkovci i “Hrvatske šume” d.o.o. 1996: 127 - 138., Vinkovci - Zagreb

- VIDAKOVIĆ, M., D. KAJBA, S. BOGDAN, V. PODNAR, J. BEČAREVIĆ 2000: Estimation of genetic gain in a progeny trial of pedunculate oak (Quercus robur L.). Glas Šum Pokuse, 37: 375-381, Zagreb

- WHITE, T. L., W. T. ADAMS, D. B. NEALE. 2007: Forest Genetics. CABI International, 682 str., London

- XIANG, B., B. LI, S. E. MCKEAND, 2003: Genetic gain and selection efficiency of loblolly pine in three geographic regions. For. Sci. 49: 196-208, Bethesda 


\section{SUMMARY}

In this study we wanted to investigate different parameters providing informations about the efficassy of orchards in producing genetically diverse progeny. We used available inventory data from the company „Croatian Forest” ltd. about the numbers and the age of ramets, as well as evidented crops in two clonal seed orchards (CSOs) of pedunculate oak : CSO „Plešćice” and CSO „Petkovac”.

For CSO „Plešćice” we used inventory data on ramets and crops for the years 2003, 2006, 2007, 2008, 2009 and 2010. and for CSO „Petkovac” for the years 2003, 2004, 2005, 2006, 2008, 2009 and 2010. After 2010 the collection of crops per clone was abandoned in both orchards and we only have data for overall crops in the orchards, until the year 2017.

We calculated the amounts and variability of acorn crops in different years, as well as projections of crops for years 2018 and 2019 based on polynomial regression curves, for all years of evidented crops between years 2003 and 2017. Results are shown in Table 1 and Figures 1 and 2. All other analysis were possible only for years in which crops were collected separately by clones.

We used Pearson's product-moment and Spearman's rank correlations to compare distributions of crops per clones between pairs of investigated years, ie. rank of clones in crops production between investigated years. Both correlations were mostly statistically significant with some exceptions (Table 2)

Clone fructification balance described by cummulative curves of acorn production in different years, per percentage of fructifying clones is shown in Figures 3 and 4. Clone balance curves in both orchards show irregular distribution of crops per clones, meaning that in investigated years minority of clones contributed to majority of crops. In conditions of equal clone fertility and maximal sinchronicity of clones, clone's contribution to crops would be in concordance with the number of its ramets (clone size). Table 3 shows that in CSO Plešćice this correlation was weaker then in CSO Petkovac and, unlike in CSO Petkovac, not significant in all years.

Estimations of effective population sizes and genetic diversity of crops in different years is shown for female clone fertility in Table 4. For calculations of biparental contribution of clones, we used three scenarios encompassing various versions of potential male contribution in effective population sizes. Results are shown in Table 5. The values of effective (status) number of parents (Np) for the first scenario, where male contribution is proportionate to the percentage of clone's ramets in the overall number of ramets of all clones, is intermediate between the other two scenarios. Lowest effective (status) number of parents $(\mathrm{NP})$ and highest values of group ancestry coefficients $(\Theta)$ result from the second scenario where male contribution is equal to female. The highest effective numbers are gained for third scenario where equal male contribution of all clones is presumed.

In both CSOs, Spearman rank correlation between female effective numbers $\left(N_{f}\right)$ and overall crops in different investigated years is statistically significant at $\mathrm{p}<0,05$ level.

These two CSOs are still filled with new ramets and are still relatively young. With increasing age and ramets' tree sizes better results in crops and its genetic diversity are expected. For implementation of measures of crops genetic diversity estimations, it is necessary to monitor successively flowering and fructification in the CSOs through the years. The monitoring can then be combined with knowledge on genetic gain and clones' breeding values obtained through recently established CSOs progeny trials. Therefore, we recommend collection of CSOs' crops separately by clones, because without expensive molecular analysis it is the only way to get relevant information of individual clones contribution to genetic diversity of crops produced in the CSOs.

KEY WORDS: Pedunculate oak, clonal seed orchards, variability of the amounts of crops in different years, genetic diversity of crops, clone fructification balance 